TEME, г. XLI, бр. 1, јануар-март 2017, стр. 277-289

Прегледни рад

DOI: $10.22190 /$ TEME1701277S

Примљено: 23. 03. 2016.

UDK 37.016:796.032

Ревидирана верзија: 26. 11. 2016.

Одобрено за штампу: 17. 01. 2017.

\title{
ЗНАЧАЈ И ВРЕДНОСТИ ОЛИМПИЈСКОГ ОБРАЗОВАЫА У ОКВИРУ НАСТАВЕ ФИЗИЧКОГ ВАСПИТАҢА У ПРОЦЕСУ ОБРАЗОВАЊА МЛАДИХ
}

\author{
Виолета Шиљак ${ }^{1 *}$, Војкан Селаковић ${ }^{1}$, Владан Вукашиновић ${ }^{2}$ \\ ${ }^{1}$ Алфа универзитет, Факултет за менаџмент у спорту, Београд, Србија \\ ${ }^{2}$ Универзитет у Београду, Факултет спорта и физичког васпитања, Београд, \\ Србија \\ violeta.siljak@alfa.edu.rs
}

\begin{abstract}
Апстракт
Настојећи да реформише постојећи систем образовања, при томе пратећи модел по коме је физичко васпитање виђено као неизоставни елемент у ширем процесу развоја личности, француски педагог барон Пјер де Кубертен ствара друштвену филозофију олимпизма на темељима моралног аспекта спортског образовања у античкој Грчкој. Дефинишући нове принципе физичког васпитања, Де Кубертенова филозофија заснивала се на јединству физичког и моралног развоја као формативних чинилаца личности, кроз усвајање хуманистичких идеала неопходних сваком друштвеном систему. Рад има за циљ да дефинише порекло и карактеристике овог процеса развијања и промовисања вредности олимпизма, као и да укаже на значај имплементације концепта олимпијског образовања у званичне образовне системе и њихове наставне програме, једног од основних едукативних циљева Олимпијског покрета на глобалном нивоу.
\end{abstract}

Кључне речи: образовање, настава, физичко васпитање, олимпијско образовање, омладина.

\section{THE IMPORTANCE AND VALUE OF OLYMPIC EDUCATION IN TEACHING PHYSICAL EDUCATION}

\begin{abstract}
In an attempt to reform the existing system of physical education, whilst following the model of education that saw physical education as a vital element in a wider process of physical education, the French pedagogue, baron Pierre de Coubertin, established a social philosophy of Olympism, based on a moral aspect of Ancient Greek sports education. By defining new principles of physical education, de Coubertin's philosophy was founded on the concept of unity between physical and moral development which is seen as a formative factor in character development. The purpose of this work is to define the origin and characteristics of this process of development and promotion of the
\end{abstract}


Olympic values, while pointing out the importance of implementing the concept of Olympic education in formal educational institutions and their teaching programs, which is one of the main educational goals of the Olympic movement worldwide.

Key words: education, classes, physical education, Olympic education, youth.

\section{УВОД}

Олимпијске игре представљају највећи спортски догађај данашњице. Међутим, њихов значај далеко превазилази спортски контекст. Олимпијске игре су уједно и највећи друштвени догађај, који окупља људе из готово свих светских земаља, настојећи тако да промовише мултикултуралну интеракцију, комуникацију, као и концепт глобалног мира у турбулентним временима, као један од важних фактора у очувању целокупне људске цивилизације.

Претечом Олимпијских игара, с обзиром на то да се не може говорити о њиховом континуитету од античког доба до данас, сматрају се Свечане игре у античкој Олимпији. Античке игре биле су рефлексија друштвеног система које га је створило, а саме су непрестано еволуирале током свог дванаестовековног трајања. Установљавајући ригорозна правила учествовања и организације, Игре су осигурале своју отпорност, због које су, заједно са својим утицајем, успеле да очувају суштинску идеологију, религиозну основу и, уопште, културу гимназија и телесног подвига, упркос великим политичким и културолошким променама које су донеле бројне епохе. Игре су допринеле да, уз ограничено културолошко наслеђе које би користили као основу, Грци готово парадоксалном разноврсношћу свог етоca, кроз интелектуалне, уметничке и телесне подвиге, развију софистициранију и разноврснију културу од било које тада присутне.

И поред чињенице да је интерпретација античких вредности у модерном контексту умногоме ограничена друштвеним нормама и принципима савременог друштва, неке од темељних идеолошких вредности античких игара успеле су да пронађу своје место у модерном друштвеном систему вредности. Наслеђе античке традиције пацифизма, морални аспекти правичности, компетитивности, култа људске изврсности, као и заједништва телесног, умног и моралног развоја служили су као инспирација педагозима широм Европе, на челу са Пјером де Кубертеном. Француски барон Де Кубертен на античким моралним основама ствара принципе савремене друштвене филозофије, коју називамо олимпизмом, а која настоји да омогући хармоничан развој личности кроз примену и усвајање ових вредности у образовном процесу младих. Де Кубертен успешно препознаје едукативни потенцијал спорта, видевши га као изузетно успешно образовно средство које се може искористити у процесу приближавања вредности и хуманистичких идеала олимпизма младима, који 
ће тиме допринети стварању мирнијег и хармоничнијег света у коме живимо.

Наглашени аспект олимпијске едукације данас има суштинску улогу у мисији Олимпијског покрета: да промовише филозофију засновану на доживљају спорта као неизоставног чиниоца у еволуцији личности. Улога спорта, као саставног дела програма наставе физичког васпитања, јесте да кроз концепт олимпизма тежи хармоничном развоју човека, стимулисањем самоспознаје и самоунапређења кроз тежњу ка изврсности како у спортској вештини тако и моралној врлини. Олимпијско васпитање такође подразумева и усвајање и спровођење универзалних етичких принципа фер-плеја, једнакости, разумевања и толеранције.

Упркос извесним потешкоћама у процесу имплементације едукативних иницијатива Олимпијског покрета у званичне образовне системе, значај и корист Олимпијског образовања су препознати, па је, према Дајани Биндер, обавеза свих потенцијалних градова домаћина Олимпијских игара да представе своје планове иницијативе за спровођење пројеката Олимпијске едукације (Binder, 2010). Како је приметио Џим Пери, један од истакнутих филозофа и педагога, који се бави едукативним аспектом олимпизма:

„Олимпијски идеали не могу се посматрати као инертни ‘иде-
али’, већ као потентне идеје које имају способност да измене
досадашња поимања спорта у образовању, посматрајући
спорт не као пуку физичку активност, већ као културолошку и
развојну активност амбициозног, успешног, избалансираног,
образованог и етичког појединца” (Рarry, 1998).

ТЕМЕЉИ ОЛИМПИЗМА - ЕДУКАТИВНЕ ОСНОВЕ АНТИЧКИХ ИГАРА У ОЛИМПИЈИ

Друштвени контекст модерних Олимпијских игара фундаментално се разликује од оног из античке Грчке, на чијим идеолошким основама почивају. Свечане игре у античкој Олимпији, једне од можда најзначајнијих, али свакако најдуготрајнијих грчких институција, биле су првенствено религиозна свечаност која се јавила након периода вишевековног политичког и културног дисконтинуитета који је уследио након краха микенске цивилизације, истовремено са појавом прве постмикенске културе у Грчкој (VIII век пре н. е.). Установљене су из потребе да се под окриљем богова зближе разједињена грчка племена (Шиљак, 2013), Игре у Олимпији представљају еволутивни корак од спонтаних и неформалних надметања (Хомер, Илијада, XXIII, Одисеја VIII, 96; Хесиод, Послови и дани, 6568) која су предстаљала фокус амбиције тадашње аристократије ка божанској слави (тиме, грч.). Она се стицала кроз култ установљен у 
славу њиховог успеха, као и одбрани легитимитета њиховог истакнутог положаја у хијерархији друштва (Хомер, Ил. II; VI; XXIII) које одбијање атлетског изазова доживљава као одрицање од свог социјалног статуса и елементарних вредности, вредно јавног презира (Хомер. Ил. V; VII).

Грчко друштво било је обликовано конфликтом из кога је произашао агон, нагон за надметањем, јединствено грчки и готово институционализовани модел „часног, узвишеног ривалитета” (Бургхарт прев. 1998) ${ }^{1}$, а метафоричка, алтернативна форма најизраженије врсте конфликта - оружаног сукоба - била су управо атлетска надметања, борбе, односно агони. Као паралелна манифестација ратног сукоба, атлетски агони успевају да очувају централно место конфликта у друштву, мењајући деструктивну природу ратног окружења атлетским борбама, које ће у исто време бити једнако верне идеалу адреје (идеал мушкости - прим. аут.), али вођење јасно дефинисаним правилима, у контролисаном окружењу у коме божанска правичност, под чијим се окриљем Игре одржавају, игра пресудну улогу.

Конфликт, у свим својим формама које, причајући о дуалности његове персонификације први дефинише, у једном од најранијих дела грчке епске поезије Хесиод (Послови и дани, 10-26) остаје пивот друштвеног живота у Грчкој током читавог дванаестовековног трајања Игара у Олимпији, имун на бројне политичке промене, представљајући важан чинилац у успостављању и одржавању хијерархије друштвене заједнице, формирања друштвеног етоса и темеља васпитања младих. Показивање физичке снаге и атлетске изврсности као отелотворења андреје, кроз јавно надметање и доказивање своје ареmе (изврсности - прим. аут.), подударало се са идеалом мушкости са којом су се могли, или чак морали, идентификовати Грци који су се надали унапређењу или чак одржавању свог друштвеног положаја или реномеа. Глорификовани победници на атлетским надметањима постају отелотворење идеала аристократске елите у потрази са херојском бесмртношћу ${ }^{2}$ и сличности са боговима (Немејска, VI, 1), у

${ }^{1} \mathrm{O}$ распрострањености конфликта у друштву и општој прихваћености етике компетитивности сведочи најпре Хесиод, који описује надметање међу суседима, грнчарима, занатлијама, песницима и просјацима (Хесиод, Послови и дани, 10-26). Међу каснијим ауторима архајског и класичног доба срећу се калистеje, односно надметања у лепоти међу женама са Лезба (Сканлон, 2002, према Алкеј, фрагмент 130) и др.

${ }^{2}$ Херојски култ у античкој Грчкој подразумевао је поштовање фигуре која није божанство из пантеона богова са Олимпа, али се на неки начин уздигла од обичних смртника. Насупрот богова који су живели на небу, хтонска, земаљска божанства подразумевала су силе које владају подземним светом, хероје, који након своје смрти својим моћима делују на људе на земљи, али и богове и богиње које руководе светом мртвих (Ларсон, 2007). 
исто време радећи у интересу шире заједнице матичног (касније демократског) полиса, која је нестрпљиво чекала да се идентификује са његовом новостеченом чашћу и угледом.

Најкасније од VI века пре н. е. (Шримптон, 1991, према Теопомопу, XXI), у Грчкој се појављују први званични објекти са сврхом праформе физичког образовања и систематског тренинга, односно гимназије и палестре, где се, сем спортске вештине, инсистира на усвајању адекватних етичких и моралних норми. Тренирање у гимназијама и палестрама осмишљено је са циљем да младе атлете кроз самоспознају искажу жељу за стицањем вештина и врлина усмерених ка достизању изврсности, али и знања о њеном немерљивом значају у грчком друштву. Како је Сократ приметио, изврсност у једној области (у овом случају атлетској дисциплини) не подразумева неопходно и општу изврсност личности, већ се она мора активно унапређивати (Платон, Лахес, 1968). Из тог разлога је учешће на Играма у Олимпији било регулисано ригорозним правилима ${ }^{3}$, а само од оних који су имали адекватне образовне основе могло се очекивати да препознају и поштују строге етичке и моралне норме надметања у Олимпији.

О значају моралне основе атлетског надметања у Олимпији свакако сведочи и релативно мали проценат случајева кршења ових норми, на које су, претећим тоном који наговештава божанску одмазду, упозоравале бронзане статуе на светилишту у Олимпији, израђене од новчаних средстава преступника (Паусанија, V). Последично, друштвено порекло као детерминанта образовања већине Грка постаје један од основних критеријума у одабиру будућих атлета. Једна од највећих гимназија у Атини - Киносарг - прихватала је чак искључиво децу која по свом пореклу одговарају нормама панхеленских надметања (Плутарх, Темистокле, I, 2; Јоанидис, Стефановић, Кариту, Шиљак \& Мијатовић, 2008). Међутим, наставак ове врсте обучавања младих атлета и њихов напредак ка Олимпији или другим панхеленским фестивалима био је условљен и њиховом способношћу за усвајањем и демонстрирањем наведених вредности пред $n е$ дотрибејима, званичницима гимназија који су непосредно били задужени, између осталог, и за процес одабира атлета (Јоанидис и сар., 2008). У овој чињеници лежи и највећи значај античке форме физичког васпитања, које је подразумевало да амбициозна потрага за изврсношћу мора објединити моралне врлине и ван контекста атлет-

\footnotetext{
${ }^{3}$ Учешће на Играма није било дозвољено непуноправним Грцима, искључујући тиме робове, метике, мотаке (децу родитеља из различитих социјалних група) и варваре, као и осуђенике за убиство или скрнављење верских објеката. Само присуство је било забрањено женама, а чак су и пуноправни Грци мушког пола били обавезни да пруже доказе о посвећеној припреми од најмање десет месеци.
} 
ског надметања, посредно доприносећи развоју комплетне личности која је поштујући установљене друштвене норме уравнотежена између жеље и потребе за самопромоцијом и жеље за доприносом добробити читавог друштва, персонификујући тако вишевековни етос читаве једне цивилизације.

\section{ПЈЕР ДЕ КУБЕРТЕН И ЗАЧЕЦИ ДРУШТВЕНЕ ФИЛОЗОФИЈЕ ОЛИМПИЗМА}

Инспирисана револуционарним археолошким открићима на подручју Грчке, укључујући и откривање локалитета Олимпије, тадашња Краљевина Грчка већ 1850-их година посебним указом најављује реоснивање Олимпијских игара које ће убрзо, иако локалног карактера, освојити пажњу европске, нарочито педагошке, јавности (Шиљак, 2013). Схвативши културолошки значај спорта у ери његове експанзије, као и његов потенцијал да подстакне мултикултурализам, мирну коегзистенцију, едукацију и комуникацију на глобалном нивоу, француски барон, педагог и хеленофил Пјер де Кубертен (1863-1937) крајем XIX века дефинише нову филозофију физичког васпитања (Pédagogie sportive) наглашавајући социјални, културолошки аспект, а нарочито образовни аспект онога што се подразумева под такозваном педагогијом олимпизма.

Де Кубертен ствара образовни систем под утицајем тадашњег енглеског система јавног школства које је традиционално укључивало физичко васпитање као средство моралног развоја. У оквиру сопствених настојања да „оживи” античке Олимпијске игре и уврсти спорт у редовни систем образовања, Де Кубертен формира филозофију која се надовезује на премису да су компетитивност и такмичарски нагон присутни у човеку од рођења, сматрајући при томе да је једина адекватна и друштвено корисна форма његовог испољавања она вођена етичким и моралним принципима који морају постати темељ едукације младих. Де Кубертенова филозофија није само темељ будућег олимпијског образовања већ рефлектује и глобални развој спорта и културе савременог доба. Основни принципи енглеског модела физичког образовања били су јачање тела кроз систематску физичку активност, посматрано као неопходно средство изградње карактера и моралних аспеката личности које ће се пренети и на остале сфере живота (Наул, 2009).

У овим принципима Де Кубертен је видео отелотворење античких образовних принципа, формирајући на основу њих своју идеју образовања коју данас промовише Олимпијски покрет. Његова социјална филозофија олимпизма је универзална, имајући за циљ трајно установљавање етичких принципа спорта као формативних чинилаца личности. Ови принципи настоје да допринесу „изградњи мир- 
нијег и бољег света едукујући младе кроз спорт ослобођен дискриминације, у Олимпијском духу, који подразумева међусобно разумевање, дух пријатељства, солидарности и фер-плеја", како је наведено у Олимпијској повељи (Olymріс Charter, 2015).

За Де Кубертена, спортисти који учествују у Олимпијским играма представљају „амбасадоре модерне едукације” који представљају спорт као средство развоја моралне личности (Наул 2009). Олимпизам је окарактерисан као универзална филозофија, промовишући вредности које готово свако друштво може препознати као пожељне, превазилазећи при томе расне, националне, класне, полне или идеолошке разлике. Иако његова филозофија несумњиво интерпретира поменуте античке вредности у контексту западноевропског друштва с краја XIX века, она настоји да унапреди актуелну социјалну праксу наглашавајући једнакост, правдољубивост и поштовање демонстриране изврсности као основне хуманистичке идеале неопходне сваком друштвеном систему.

На тај начин се дошло до вредносне основе идеологије олимпизма, посматране као животне филозофије, која апострофира балансиран развој личности чији је битан чинилац и физички развој кроз спорт. Олимпизам повезује културу и едукацију тражећи начине да установи животни модел који проналази радост у труду вреднујући образовни потенцијал позитивног примера и поштовања фундаменталних, универзално прихваћених етичких принципа, промовишући при томе мир и разумевање кроз комуникацију, мултикултурални развој и борбе против сваке врсте дискриминације (Олимпијска повеља, 2015).

Олимпијско образовање подразумева процес развијања и промовисања ових вредности - што је један од његових главних едукативних циљева на глобалном нивоу - при чему је спорт једно од најефикаснијих средстава за њихово постизање, без обзира на чињеницу да су ове вредности подложне извесним променама услед различите интерпретације и њиховог прилагођавања нормама и традицијама друштва у коме су примењена.

\section{ПЕДАГОГИЈА ОЛИМПИЗМА И ИМПЛЕМЕНТАЦИЈА \\ ОЛИМПИЈСКОГ ВАСПИТАҢА У ПРОГРАМЕ ОБРАЗОВНИХ ИНСТИТУЦИЈА}

Наредни значајан корак у процесу еволуције спортске педагогије, односно Де Кубертенове идеје олимпијске педагогије, представља оснивање Интернационалне олимпијске академије у Олимпији 1961. године. Напредак је уследио након вишедеценијског периода стагнације развоја спортске едукације. Под утицајем најпре политичких, а затим и осталих фактора, Де Кубертенова визија почиње 
се деформисати у бројним алтернативним верзијама квазиолимпијске едукације кроз реализацију програма који су имали све мање заједничког са првобитном визијом. Пери (Parry 1998, према Parry 1988) препознаје педагошки потенцијал спорта спровођеног у контексту олимпијских вредности - тврдећи да је потребно развити систематски приказ људске културе и искуства која препознаје заслугу физичке активности, груписане под називом физичко васпитање, а које би тврдњама о људској изврсности и капацитетима, као и важности различитих културолошких форми, развило аргументе који би оправдали место физичког васпитања у образовном систему. Формирањем Интернационалне олимпијске академије, међународног иентра за олимпијске студије, образовање и истражсивање начињен је круцијалан корак ка успешној имплементацији концепта олимпијског образовања у званичне образовне системе.

Ширење Де Кубертенове „олимпијске” филозофије физичког васпитања на међународном нивоу убрзо је уследило оснивањем националних олимпијских академија, када се програми олимпијског образовања уводе у бројне земље, од чега је од посебне важности њихово укључивање у званичне програме наставе физичког фаспитања у основним школама. Упркос тренду комерцијализације читавог Олимпијског покрета - што је један од највећих изазова постављених пред покрет у последње две или три деценије - захваљујући напорима МОК и националних комитета на успостављању образовног кредибилитета, едукативни програми, посебно наглашавајући промоцију вредности фер-плеја, шире поље деловања са школа и на клубове, спортска удружења, али и целокупну друштвену јавност (Милер [Müller], 2010).

У Европи се ови програми најпре уводе у Немачкој, први пут у време одржавања Игара XX Олимпијаде 1972. године у Минхену. A један од позитивних примера представљају и програми инспирисани Олимпијским играма који су се релативно брзо проширили у школском систему од 1969. године. Програм је подразумевао такмичење деце различитог школског узраста у тринаест спортских дисциплина са визијом учешћа на Олимпијским играма, а са педагошким циљем ка омогућавању позитивне идентификације деце са успехом свог тима. (Милер 1988).

Од половине наредне деценије, након овог, експерименталног периода, може се приметити значајнији ниво стандардизације Олимпијског образовања у осталим земљама, и постепено дефинисање фундаменталних принципа Олимпијске педагогије. Различите форме приступа олимпијском образовању, које првенствено леже у начину на који се едукативни стандарди трансформишу у контекст олимпијске педагогије, дате су од стране Биндер (2002), а подразумевају: приступ оријентисан ка усвајању теоријског знања из области олим- 
пизма, кроз изучавање историје античких и модерних Олимпијских игара; тзв. експериментални приступ, који наглашава учешће ученика на „олимпијским” фестивалима и такмичењима, као и промовисање међународне кооперације и комуникације на школском нивоу уз акцентовање усвајања олимпијских вредности фер-плеја и толеранције; приступ који наглашава индивидуални развој личности кроз спорт, а који се заснива на идеји индивидуалног и социјалног развоја које долазе као резултат унапређења физичких способности кроз напор уложен у самоусавршавање и надметање са другима; тзв. lebenswelt (свет живота, прим. аут.) и приступ који сажима олимпијске идеале као мотиваторе даљег образовања и развоја личности у свим, ванспортским аспектима живота (Биндер, 2010).

Милер (2010) истиче пет основних теоретских карактеристика модерног Олимпијског образовања које се могу сматрати наследством Де Кубертенове филозофије:

- изражени концепт хармоничног развоја човека;

- идеја потрага за изврсношћу кроз демонстрирање високог нивоа перформанси, при чему су научна и уметничка достигнућа третирана у истом рангу са спортским;

- подразумевана, добровољна веза између етичких принципа попут фер-плеја, аматеризма и једнакости шанси, као и одлучност ка спровођењу ових принципа;

- концепт мира и разумевања међу нацијама, рефлектована у поштовању и толеранцији међу појединцима и

- промоција еманципације у спорту и кроз спорт.

Методологија имплементације олимпијског образовања у званичан план и програм наставе физичког васпитања у школама заснива се на: теоријским предавањима кроз коришћење доступног едукативног материјала, која се тичу историје и порекла Олимпијског покрета, принципа, симбола и начела олимпизма из Олимпијске повеље и др.; у зависности од узраста ученика, примењују се различити приступи који подразумевају анимирање ученика кроз коришћење филмова, књига, интерактивних игара и др.; уметничким активностима попут моделарства, сликања, игре, музике и др.; кроз комбинацију визуелних и активности из области културе попут формирања Олимпијског музеја у просторијама школе и сл.; физичка активност која акцентује моторички развој - темељ олимпијског образовања, укључује активности које су у форми спортског такмичења са акцентом на развој социјалних вештина у окружењу руковођеном олимпијским принципима. Биндер наводи, заснивајући се на теорији моралног развоја, најважније циљеве образовања ученика школског узраста: 1) дефинисање појма поштења (фер-плеја) и усвајања механизама кооперације и заједничког решавања конфликта - проблематике која је у средишту њиховог интересовања, с обзиром на то да се 
налазе у узрасту у коме развијају капацитете за препознавање другачијих погледа на свет од свог и 2) пружање помоћи ученицима од стране наставника у дефинисању способности њиховог моралног резоновања кроз „примере који стварају морални конфликт излажући ученике вишим моделима размишљања од сопственог", с обзиром на то да се „стимулација моралног развоја код деце јавља када су суочена са истинским, тешким моралним конфликтом" (Биндер, 2010).

Један од начелних циљева Олимпијског образовања јесте да образује и наставнички кадар у образовно-васпитним институцијама, који ће стеченим знањем о принципима олимпизма у контексту едукације моћи приближити проблематику на адекватан и разумљив начин. Један од проблема имплементације ове врсте образовања у школске програме, међутим, лежи и у чињеници да су овакви пројекти условљени, између осталог, и самим нивоом организације школске установе и њене ефикасности у спровођењу овог, мултидисциплинарног типа програма. Стога су, и поред воље за њихово спровођење, потребне конкретне мере и стратегије за њихову примену, па олимпијско васпитање остаје независно од формалног образовања и може бити примењено у свим окружењима, чак и ван спортског контекста. Упркос томе, олимпијско васпитање испуњава своју образовну улогу докле год испуњава образовне задатке које наводи Биндер (2010), а који подразумевају:

- Обогаћење људске личности кроз физичку активност и спорт, а који су повезани са културом и подразумевано трају читав живот;

- Развијање осећаја људске солидарности, толеранције и узајамног поштовања кроз дух фер-плеја;

- Подстицање мира, узајамног разумевања, поштовања различитих култура, заштиту околине, основних људских вредности и обзира у складу са регионалним и националним потребама;

- Подстицање тежње ка највишим достигнућима у складу са основним олимпијским идеалима;

- Развијање осећаја за континуитет људске цивилизације кроз истраживање античке и модерне олимпијске историје.

\section{ЗАКЉУЧАК}

На Олимпијском покрету остаје да обезбеди будућност идеји олимпијског образовања у школама и сагледа његов едукативни потенцијал у оквиру школства као образовног система и ван њега. Школски програми морају јасно дефинисати олимпијски елемент њиховог образовања, настојећи да створе ефикасан систем имплементације који неће створити само интересантнију верзију постојеће наставе физичког васпитања већ вишеслојни систем образовања који 
се заснива на хуманистичким основама олимпизма постављеним од стране Пјера де Кубертена.

Поштујући Де Кубертенову дефиницију олимпизма као стања свести, а не техничког система, олимпијско образовање допринеће усвајању његових етичких, моралних и едукативних принципа. Циљеви овог вида образовања јесу да међу ученицима створи механизме препознавања разлика између компетитивности, која се сматра средством постизања и показивања изврсности, и агресивности у спортском контексту. Циљ је и створити доживљај спорта и Олимпијског покрета као простора промоције људских права, комуникације и разумевања међу људима, самоспознаје кроз спорт и проналажење радости у труду који се улаже у усавршавање и стремљење ка спортском циљу.

Олимпијско образовање ствара позитивне ставове према спорту омогућавајући ученицима да критички сагледају све видове испољавања нетолеранције и неетичког понашања, што представља доказ усвајања вредносних критеријума олимпијског покрета. Ови критеријуми релевантни су и у свим аспектима друштвеног живота, а принципи и вредности опште применљиви. Тиме едукација по принципима олимпизма доприноси стварању универзално прихваћеног, хуманистичког модела понашања који превазилази оквире спортског, а образовни процес може се посматрати као круцијална фаза у сложеном процесу развоја комплетне личности.

\section{ЛИТЕРАТУРА}

Athenaeus, Charles Duke Yonge. (1853) The Deipnosophists Or, Banquet of the Learned of Athenaeus. London: H.G. Bohn. Преузето 13. 10. 2015. ca http:// digicoll.library.wisc.edu/cgi-bin/Literature/Literature-idx?type=browse \&scope= Literature.DeipnoSub

Aristotle., Cooke, H. P., Longinus., \& Demetrius. (1965). Aristotle in twenty-three volumes. Cambridge, Mass: Harvard University Press. Преузето 1. 11. 2015. ca http://www.perseus.tufts.edu/hopper/text?doc=Perseus\%3Atext\%3A1999.01.0058

Binder, D. (2010): Teaching Olympism in schools: Olympic Education as a focus on values education: university lectures on the Olympics. (onlajn članak)

Burckhardt, Jacob, i Oswyn Murray. (1898) The Greeks and Greek Civilization. New York: St. Martin's.

Garland, L., \& Dillon, M. (2000). Ancient Greece: Social and Historical Documents from Archaic Times to the Death of Socrates (c.800-399 BC). Taylor \& Francis.

Hesiod, Hugh G. Evelyn-White. (1914) The Homeric Hymns and Homerica with an English Translation. Works and Days. Cambridge: Harvard UP.

Homer, A. T. Murray, PH.D. (1925) The Iliad. Cambridge: Harvard UP.

Homer, A.T. Murray, PH.D. (1919) The Odyssey. Cambridge: Hardvard UP

Јоанидис, Т., Стефановић, Ђ., Кариту, М., Шиљак, В., \& Мијатовић, С. (2008). Улога и значај гимназије у припреми младих за такмичење на Олимпијским играма у античкој Грчкој [The Role and Significance of Grammar Schools in the Process of Youth Preparation for the Olympic Games in Ancient Greece]. Физичка култура, 62(1-2), 66-83. 
Larson, J. (2007). Ancient Greek cults: A guide. New York: Routledge.

Müller, N. (1988) Olympism and "Sport for all", International Olympic Academy: 28th Youth Participants Session, International Olympic Academy, pp. 188-200.

Müller, N. (2010) Olympic education: university lecture on the Olympics [онлајн]. Barcelona: Centre d'Estudis Olímpics (UAB).

Naul, R. (2009). Olympic Pedagogy as a Theory of Development of Ethical and Humanistic Values in Education. y: International Olympic Academy (ed.) Proceedings of the 9th International Session for Directors of National Olympic Academies (pp. 27-40). Athens: Livani.

Olympic Charter (2015). Lausanne: International Olympic Committee, pp. 13-14. Преузето 5. 11. 2015. ca http://www.olympic.org/Documents/olympic_charter_ en.pdf.

Parry, J. (1988). Olympism at the Beginning and End of the Twentieth Century (IOA Proceedings, pp. 81-94)

Parry, J. (1998) The Justification of Physical Education (y Green K \& Hardman K. Physical Education - a Reader Meyer \& Meyer, str. 36-68).

Pausanias., W.H.S. Jones, Litt.D., and H.A. Ormerod. (1918) Description of Greece with an English Translation. Cambridge: Harvard UP.

Plutarch., \& Perrin, B. (1914). Plutarch's lives: Volume 2. London: Heinemann.

Plutarch., Shilleto, A. R. (1898). Plutarch's Morals. London: G. Bell and Sons.

Pindarus, (1952). Ode i fragmenti: Pindar. [Odes and Fragments], Preveo Ton Smerdel. Zagreb: Matica Hrvatska.

Plato, Bury, R. G. (1968). Plato: In twelve volumes. London: W. Heinemann. http://www. perseus.tufts.edu/hopper/text?doc $=$ Plat. + Phaedrus +227 a\&redirect $=$ true

Scanlon, T. F. (2002). Eros \& Greek athletics. New York: Oxford University Press.

Strabo, Jones, H. L., \& Sterrett, J. R. (2005). Geography. Cambridge, Mass: Harvard University Press.

Shrimpton, G. S. (1991). Theopompus the historian. Montreal [Que.: McGill-Queen's University Press.

Шиљак, В., (2013). Олимпизам [Olympism]. Београд: Алфа универзитет - Факултет за менаџмент у спорту.

Xenophon., Brownson, C. L., Todd, O. J., Marchant, E. C., Bowersock, G. W., \& Miller, W. (1968). Xenophon: In seven volumes. London: W. Heinemann. Преузето 12. 11. 2015. ca http://www.perseus.tufts.edu/hopper/text?doc=Perseus\%3Atext\% 3A1999.01.0210\%3 Atext\%3D Const.+Lac.

\title{
THE IMPORTANCE AND VALUE OF OLYMPIC EDUCATION IN TEACHING PHYSICAL EDUCATION
}

\author{
Violeta Šiljak, Vojkan Selaković, Vladan Vukašinović \\ ${ }^{1}$ Alfa University, Faculty of Sport Management, Belgrade, Serbia \\ ${ }^{2}$ University of Belgrade, Faculty of Sport and Physical Education, Belgrade, Serbia
}

\section{Summary}

The modern Olympic Games are based on the principles of the ancient Olympic Games. Their modernized moral principles are the basis of the Olympic Charter, on which the entire Olympic Movement is based. As the largest social and sporting event of today, the Olympic games represent an important factor in preserving global peace through 
promotion of multiculturalism and communication between nations connected by sport, through transcending differences and cultivating universal ethical and moral principles, included in the philosophy of Olympism.

Olympism, as a social philosophy, was first conceptualised by a French pedagogue, Baron Pierre de Coubertin, who - inspired by the ancient Greek ideals of harmonious development of character through the context of athletic competitions in ancient Olympia formed new principles of education, which insisted on the inclusion of sporting activities in the formal teaching process in educational institutions. The goal of de Coubertin's approach to education was to improve the present social practice through the context of sport as a means of moral character development, emphasising basic humanistic ideals defined by the principles of Olympism. These universal principles, relevant to any society, include adopting the model of behavior that finds joy in effort, rather than a relentless pursuit of winning, valuing ethical principles, pacifism, tolerance, and multiculturalism.

Olympic education is a process through which these values are promoted and developed, and later implemented in the official formal educational programs, with particular emphasis on primary schools, which is, finally, one of the main educational goals of the Olympic movement. It is based on theoretical lectures through the use of accessible educational material related to the history and origin of the Olympic movement, principles, symbols, and principles of Olympism from the Olympic Charter. In addition to the theoretical approach, Olympic education also operates through physical activity that encourages motor development of young people in the form of sports competitions with the emphasis on the development of social skills in an environment guided by the Olympic principles. 